Article

\title{
Evaluation of Gonadal Tissue to Validate Size at Reproductive Maturity in Kemp's Ridley Sea Turtles Found Stranded in Texas, USA
}

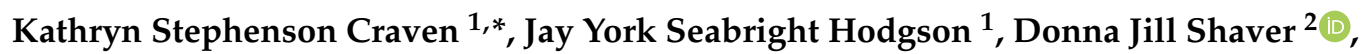 \\ Jennifer Shelby Walker ${ }^{2}{ }^{\circledR}$, Martha Ramona Villalba-Guerra ${ }^{2}$ and David William Owens ${ }^{3}$ \\ 1 Department of Biology, Georgia Southern University - Armstrong Campus, 11935 Abercorn St., \\ Savannah, GA 31419, USA; jhodgson@georgiasouthern.edu \\ 2 Division of Sea Turtle Science and Recovery, Padre Island National Seashore, National Park Service, \\ P.O. Box 181300, Corpus Christi, TX 78480, USA; donna_shaver@nps.gov (D.J.S.); \\ jennifer_shelby_walker@nps.gov (J.S.W.); martha_villalba-guerra@nps.gov (M.R.V.-G.) \\ 3 Department of Biology, College of Charleston, 66 George St., Charleston, SC 29424, USA; owensd@cofc.edu \\ * Correspondence: kcraven@georgiasouthern.edu
}

Received: 7 April 2019; Accepted: 6 May 2019; Published: 9 May 2019

\begin{abstract}
The Kemp's ridley, Lepidochelys kempii, is the most endangered sea turtle in the world. Anthropogenic mortality of Kemp's ridleys has been well documented in the Gulf of Mexico (GOM), USA. We evaluated the reproductive maturity of $75 \mathrm{Kemp}$ 's ridley sea turtles found dead on GOM beaches on Mustang Island and North Padre Island, Texas, USA, 1994-1999. Straight carapace length (SCL) ranged from 40.8 to $68.7 \mathrm{~cm}$. Preserved gonads and associated tissues were examined and measured. Gonadal measurements were then compared with SCL. Adults and juveniles shared a larger range of carapace measurements than expected, supporting the idea that juveniles spend several years in a pubertal state. Our results suggest caution when using SCL, tail length, or curved front claws alone as indicators of sexual maturity. In fact, SCL can be used to discern adults from juveniles with more predictive power when coupled with testis length or oviduct length measurements, thus allowing endangered species managers to more clearly identify demographic shifts in the number of mature animals, which can precede population changes. This study shows that information gained from the examination of stranded sea turtles allows wildlife managers to make more informed decisions regarding conservation priorities.
\end{abstract}

Keywords: Kemp's ridley; sea turtle size at maturation; assessing maturation; sea turtle puberty

\section{Introduction}

The Kemp's ridley, Lepidochelys kempii, is the most endangered of the seven species of sea turtles [1]. Kemp's ridleys inhabit the western Atlantic Ocean and the Gulf of Mexico, residing primarily in the latter during adulthood [2,3]. Following a severe period of population decline that lasted through 1985, when only 702 nests were documented worldwide [4], a comprehensive conservation plan between the USA and Mexico turned the tides and redirected the Kemp's ridley away from the edge of extinction [5]. The implementation of the Bi-National Recovery plan [6] allowed for the combined protection of sea turtles and nests on the beach, greater protection in the offshore critical habitat, and the use of turtle excluder devices in trawl fisheries, which had been a widely documented source of mortality [7-10].

Over time, stronger protections enabled Kemp's ridley recruitment into the reproductive population to increase for decades [4,11]. Near exponential recovery continued until 2009 [12,13]. In 2010, there was an increase in the number of stranded Kemp's ridleys found in the northern Gulf of Mexico (GOM), believed to be related to fisheries interactions, the Deepwater Horizon oil 
spill, and associated clean-up activities [12-14]. These and other types of anthropogenic mortality have been well documented in the southeastern Atlantic [15], and in the GOM [7,16], where serious concerns for the Kemp's ridley population persist. A stranded sea turtle is one that is found washed ashore or floating, either dead or alive and imperiled. The number of stranded Kemp's ridleys (over $10 \mathrm{~cm}$ straight carapace length (SCL) found annually in Texas currently exceeds 100 [17]. Useful information is gathered from examination and necropsy of stranded sea turtles, including sex and age-class determination. The accuracy of age-class (juvenile vs. adult) and sex determination of stranded animals is vital to record keeping and the long-term assessment of population demographics.

Data from stranded sea turtles have been used by modelers to evaluate Kemp's ridley population status $[15,18]$ and to project levels of age-based mortality and population structure $[19,20]$. Age determination estimates of wild turtles are approximate. Consequently, it is often difficult to tell the age or reproductive status of a stranded turtle [21-23].

The goal of this project was to evaluate the state of reproductive maturity using gonadal tissues from 75 Kemp's ridleys found stranded between 1994-1999 on Mustang Island and North Padre Island, Texas, USA, on the Gulf of Mexico. Using information collected from these stranded turtles, we evaluated if the carapace length alone could be sufficient to determine if it was an adult. The predictive value of gonad measurements was also investigated.

This information could be used to track population losses more accurately given the resources available at the time a stranded turtle is encountered. In retrospect, the time period when these samples were collected, 1994-1999, marked the beginning of the exponential recovery of the Kemp's ridley population and an increase in fisheries regulations and compliance [9]. Results provide insight into the size range of subadults, the threshold of adulthood, and a baseline by which we can judge changes in body size/maturity relationships that might be taking place in the current, larger population.

\section{Materials and Methods}

\subsection{Tissue Collection}

Gonadal tissue from Kemp's ridleys found stranded from 1994 through 1999 was collected during necropsy at Padre Island National Seashore. All samples were preserved in $10 \%$ formalin and accompanied by data collected at stranding, including straight carapace length (nuchal notch to posterior tip; SCL). Preserved tissue was identified as male or female. Most samples were very compact and needed to be rinsed under water to facilitate evaluation. Tissues were spread out on a flat surface gently to avoid tearing or stretching prior to measurement collection. Samples were initially assessed blind (using the ID number only) to avoid bias. Macroscopic inspection was used to determine sex and age class for each individual. Individuals without gonad measurements were not included for analyses (55 of 75 samples were included).

\subsection{Evaluation of Female Gonads}

Oviducts were determined to be complete if a portion of the anterior oviduct (infundibulum) was present. Oviduct length was recorded in centimeters. The diameter of the oviduct was taken with Vernier calipers at the base where it would meet the cloaca, and at the midpoint of the length. Associated tissues such as kidney or lung were recorded to corroborate gonad location.

Measurements of individual follicles were taken using Vernier calipers. Reproductive maturity was indicated by the presence of corpora lutea and corpora albicantia in the ovary, ovarian follicles in excess of $2 \mathrm{~cm}$, documentation of oviductal eggs at the time of gonad collection, or history of nesting based on flipper tag data. Ovaries were described according to appearance and degree of maturity. Measurements were taken of representative vitellogenic, atretic, primary, and primordial follicles. Relative density (follicles per square centimeter) of primordial follicles was also noted. In a subset of the samples, histological evaluation of the gonad tissue was used to validate the assessment of maturity. 


\subsection{Evaluation of Male Gonads}

Length and width of testes were measured with Vernier calipers. Epididymal lengths and diameters were measured, if present. The state of the epididymis was described and cross-referenced with reported gonadal development and the time of year the stranding was found. Males were classified as adult if they had a prominent epididymis (indicating sperm storage) and testicular length greater than $10 \mathrm{~cm}$. A subset of testes were sampled and maturity was validated with histological evaluations.

\subsection{Histology}

Representative samples of gonads from adult males $(N=2)$, juvenile males $(N=6)$, and adult females $(N=5)$ were sent to the Texas A\&M School of Veterinary Medicine to have slides made from the tissues. Samples were sectioned and stained with hematoxylin and eosin. Slides were observed at $400 \times-1000 \times$ with a light microscope to assess the spermatogenic activity of testicular samples and to verify the appearance of corpora lutea from ovarian samples.

\subsection{Statistical Analysis}

To prepare the data for analysis, each individual's gonad measurements were averaged if pairs were present or used measurements for only one gonad if the other was damaged.

Relationships between age class (adult or juvenile) and sex were tested using a series of four linear discriminant analysis functions with the morphometric measurements of SCL, oviduct length, oviduct width, testis length, and testis width. Linear discriminant analysis was the best fit for our unbalanced data set (38 males and 17 females; 12 adults and 43 juveniles); discriminant analysis shows no degradation under this circumstance $[24,25]$. All statistical calculations were performed with the NCSS 2007 [26] software package.

We first tested the classification of animal age class (adult or juvenile) based solely on SCL (discriminant function 1). Neither sex classifications nor gonad predictive variables could be separately factored into this single model. To address this limitation, we separately tested the classification of animal age class using SCL, gonad length, and gonad width with stepwise selection for inclusion of each predictor at $\alpha=0.1$ and exclusion at $\alpha=0.2$ for females (discriminant function 2) and males (discriminant function 3). Finally, to remove the imbalance between the number of males and females, we used a random number generator to remove 21 males from the data set and tested the classification of animal age based solely on SCL (discriminant function 4).

\section{Results}

The samples collected from females were assessed independently and cross-referenced with data collected at stranding, including SCL. Characteristics of adult females included records of shelled eggs in the oviduct or body cavity, flipper tags that could be traced to previous nesting activity, and oviducts in excess of $300 \mathrm{~cm}$. Juvenile females had shorter, immature oviducts, no shelled eggs, no previous nesting history, no ovarian scar tissue, and a high density of primordial follicles. Adults and juveniles overlapped with respect to SCL (Figure 1). There was a clear demarcation between adult females, whose ovaries had corpora lutea and follicles over $2 \mathrm{~cm}$ in diameter (Figure 2A), and juvenile females, whose ovaries had only small follicles (Figure 2B) and no evidence of scar tissue (corpora lutea). Juveniles also had oviducts that were shorter in length (Figure 1), immature (narrower, less muscular), and ovaries that were immature. A total of eight adults and 25 juveniles were designated by referencing field collected data, identical to the categories determined via tissue examination.

Based on gonadal examination for males, eight adults and 34 juveniles were designated. Adult males had testes greater than $10 \mathrm{~cm}$, yet overlapped in SCL measurements with juvenile males, SCL 59-64 cm, which had immature testes (Figure 3). Samples from six juvenile testes were verified with histological analyses. The pubertal state of the males was not obvious from external observations of carapace length or secondary sexual characteristics (tail length or curved claws) alone. These results 
were cross-referenced with information collected at stranding, including SCL, mention of a long tail, and the presence of enlarged curved claws on front flippers. In males, field assignments of maturity based on external examination alone did not agree with conclusions made from the study of gonad tissue. Some pubescent males exhibited external signs of maturation, but did not have mature testes. Tissue samples taken from testes for histological validation of maturity were representative of the physiological activity expected (either adults in active spermatogenesis or non-mitotic juveniles) and also representative of samples documented in previous studies [27-30].

\section{Female Kemp's Ridley Strandings}

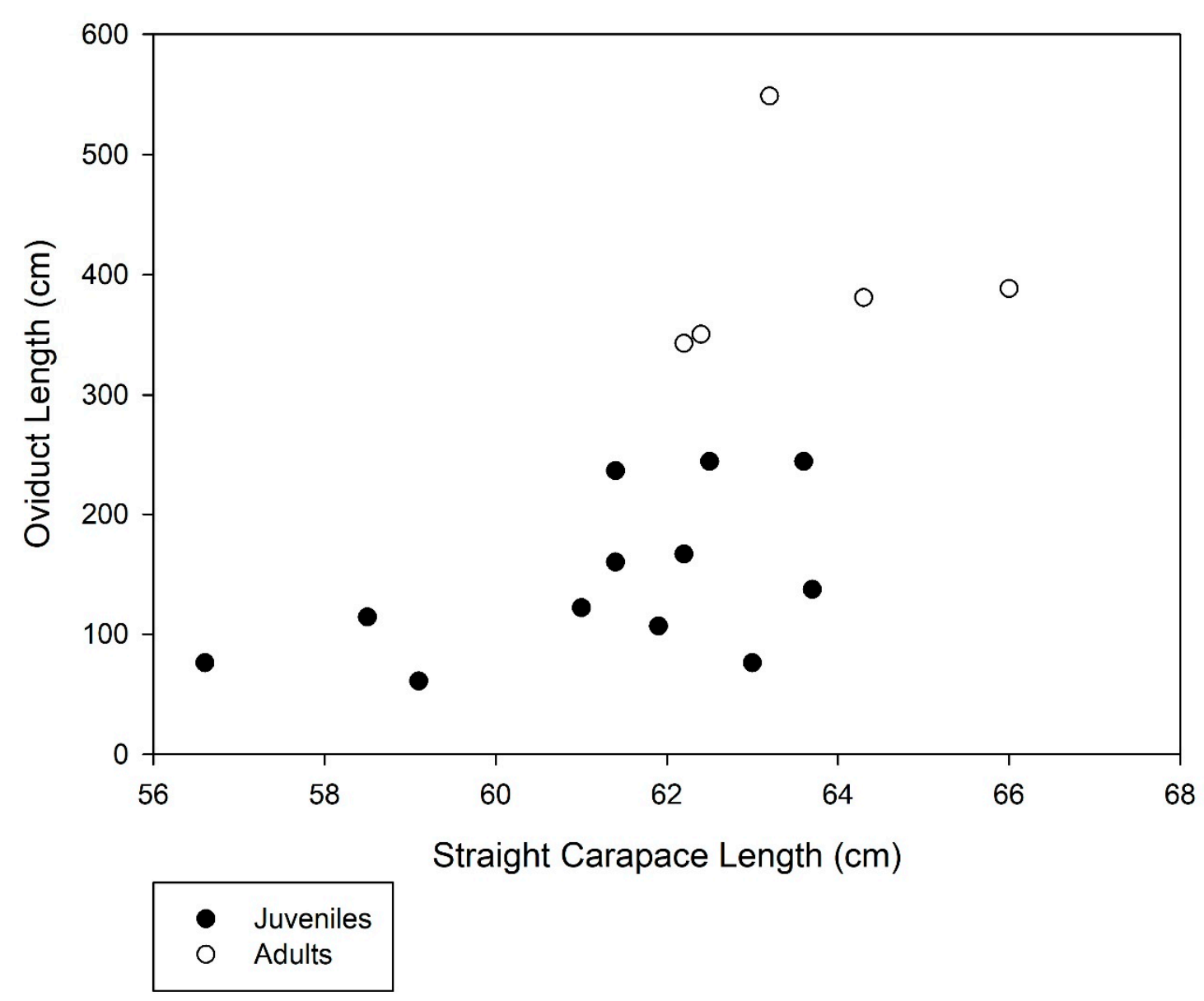

Figure 1. Comparison between the oviduct length and straight carapace length measured in stranded female Kemp's ridley sea turtles, Lepidochelys kempii. 

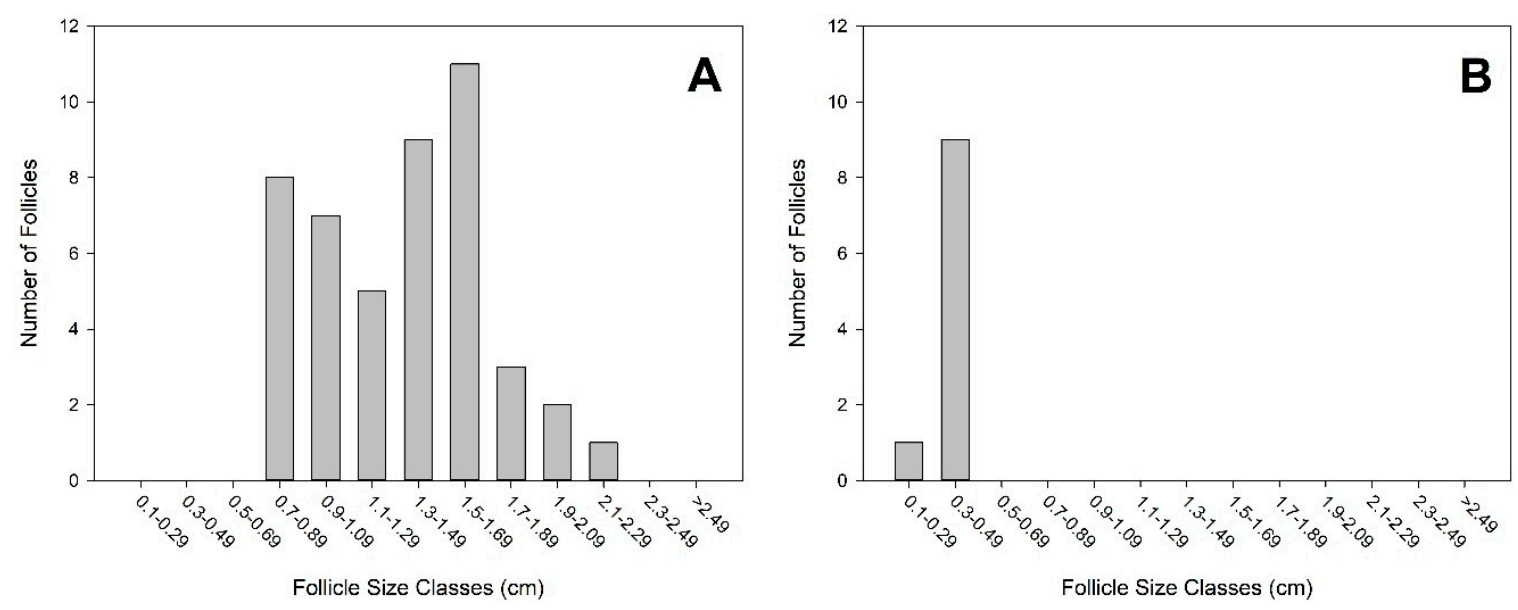

Figure 2. Numbers of ovarian follicles measured in two individual female Kemp's ridley sea turtles, Lepidochelys kempii, found stranded in Texas, USA, in 1997. (A) Ovarian follicle measurements from an adult. (B) Ovarian follicle measurements from a juvenile.

SCL was a significant predictor of reproductive state in three of four discriminant functions, with the female-only model (discriminant function 2) being the exception. Because SCL was a significant predictor for the male model (discriminant function 3), but not for the female model, we tested the assumption that the sex imbalance was driving the success of the unbalanced mixed model (discriminant function 1) by randomly removing males to create a balanced model (discriminant function 4). While the balanced model had slightly lower discriminating power than the unbalanced model, it still demonstrated strong predictive success of the reproductive state for both sexes, suggesting that SCL is a reliable predictor in a mixed population. The number of correctly classified females in both of these models showed that male SCL was not artificially inflating predictive power. However, discriminant ability is maximized when coupled with testis length or oviduct length, rather than the width of these organs.

Using SCL as the only factor, discriminant analysis correctly classified $78.2 \%$ of individuals in the mixed group, with 11 of $12(91.6 \%)$ adults correctly classified and 32 of $43(74.4 \%)$ of juveniles correctly classified (discriminant function 1). SCL was a significant predictor $(\mathrm{F}=22.2, p<0.001)$. For females, using gonad measurements and SCL, the model predicting female age class from stepwise selection of morphometric measurements had a 100\% success rate, correctly categorizing 5 adults and 12 juveniles (discriminant function 2). Oviduct length was a significant predictor ( $\mathrm{F}=48.1, p<0.001)$, but neither SCL $(\mathrm{F}=0.08, p>0.785)$ nor oviduct width $(\mathrm{F}=0.53, p>0.478)$ were significant. For males, using gonad measurements and SCL, the model predicting male age from stepwise selection had an $81.6 \%$ success rate, correctly classifying 5 of $7(71.4 \%)$ adults and 26 of $31(83.9 \%)$ juveniles (discriminant function 3). SCL $(\mathrm{F}=17.4, p<0.001)$ and testis length $(\mathrm{F}=13.8, p<0.001)$ were significant predictors, but testis width was not $(\mathrm{F}=5.9, p=0.19)$.

After 21 males were randomly removed to create an equal sex distribution, the model correctly classified $73.5 \%$ of individuals, with 7 of $7(100 \%)$ adults correctly classified and 18 of 27 (66.7\%) juveniles correctly classified (discriminant function 4). SCL was a significant predictor ( $F=9.47$, $p<0.005)$. Compared to the first function (unbalanced, mixed sex sample), this function demonstrated lower predictive performance. 
Male Kemp's Ridley Strandings

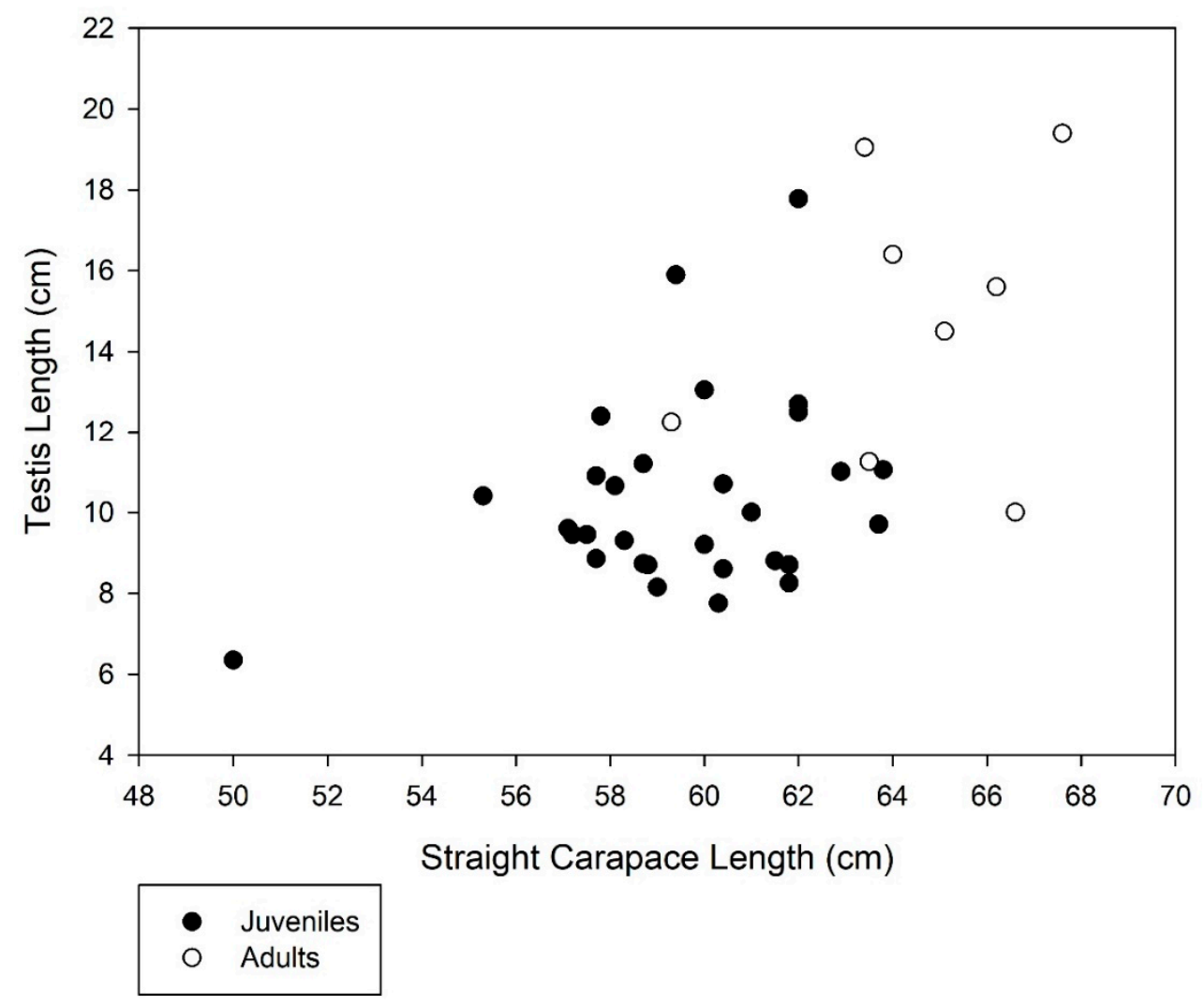

Figure 3. Comparison of testis length and straight carapace length measured in male Kemp's ridley turtles, Lepidochelys kempii, found stranded in Texas, USA, from 1994 through 1999.

\section{Discussion}

Limited numbers of studies on puberty in reptiles exist [31]. Time to maturity in reptiles can vary greatly within species, dependent on many factors, and size is more often a more reliable predictor of reproductive maturity than age [31]. Though several studies have focused on estimating age and size at maturity of Kemp's ridley sea turtles as well as the variation in size at maturation [23,32,33], this is the first study to test the relationship between gonad measurements and carapace length for age-class designation in Kemp's ridley sea turtles. Previous studies have used growth rate estimates, variations in rates of skeletal growth, and size of nesting females to estimate size at maturity and have also noted the relatively large variation we describe, and thus support the need to adjust Kemp's ridley population models $[23,33,34]$. This variation was taken into account during the most recent population assessment [18].

Using SCL alone, the data presented for these $75 \mathrm{Kemp}$ 's ridley strandings would have assigned turtles with SCL $60 \mathrm{~cm}$ and higher as adults [35], and those less than $60 \mathrm{~cm}$ as juveniles. A total of 21 females and 24 males could have been categorized as adults without further examination. Instead, sixteen adults (eight males and eight females) were identified by examination of gonadal tissues. The discriminant analysis determined there is power in using SCL to determine adult age class, but as long as resources and the condition of the turtle allow for a necropsy, the results will be more accurate if gonad length is included in the assessment. Estimates of the size at adulthood are variable, and it is agreed that it spans a range of SCL measurements. Using "rapprochement" skeletal growth mark associated with maturation, Avens et al. estimated size at sexual maturity at 53.3-68.3 cm SCL, with an 
average of $61 \mathrm{~cm}$ [23]. Nesting adult female Kemp's ridleys have been documented within that range, with recorded SCL measurements spanning from 54.8-78 cm [3,32].

There is an extended pubertal time period for the Kemp's ridley that appears to last many years based on the decrease in growth rate as the they approach maturity $[23,33]$. This is also evident based on the size at first nesting reported for a group of head-started Kemp's ridleys, which varied by up to $8 \mathrm{~cm}$ SCL [14].

Knowledge of variation in size at maturity and seasonal variations in gonad size and appearance is essential for future population assessments that incorporate documented size of stranded Kemp's ridley turtles [18]. In the current study, one pubertal male found in March (mating season, Figure 4), with $62 \mathrm{~cm}$ $\mathrm{SCL}$, had testes that averaged $12.5 \mathrm{~cm}$, which, like his epididymal tissue, were underdeveloped and inactive. Those tissues were not consistent with an adult male [27,36,37]. Ovarian tissue is characterized by the presence of atretic follicles and corpora lutea in the post-nesting season [37], both of which were found on the tissues of stranded adults in July through October (Figure 4) along with a less muscular oviduct. Gonadal regression for adult males begins in May, when testosterone levels drop and a visible decrease in the diameter and activity of seminiferous tubules can be seen [28]. Testes examined for adult male Kemp's ridleys collected prior to the seasonal reproductive period (November-March) were larger, and unlikely to be mistaken for those of a juvenile. Histological validation indicated that some of the large juveniles showed signs of early spermatogenesis. Post-reproductive-season males were more challenging to evaluate, in some cases requiring multiple data endpoints (gonad length, $\mathrm{SCL}$, and secondary sexual characteristics) to complete the assessment.

\section{Strandings by Month}

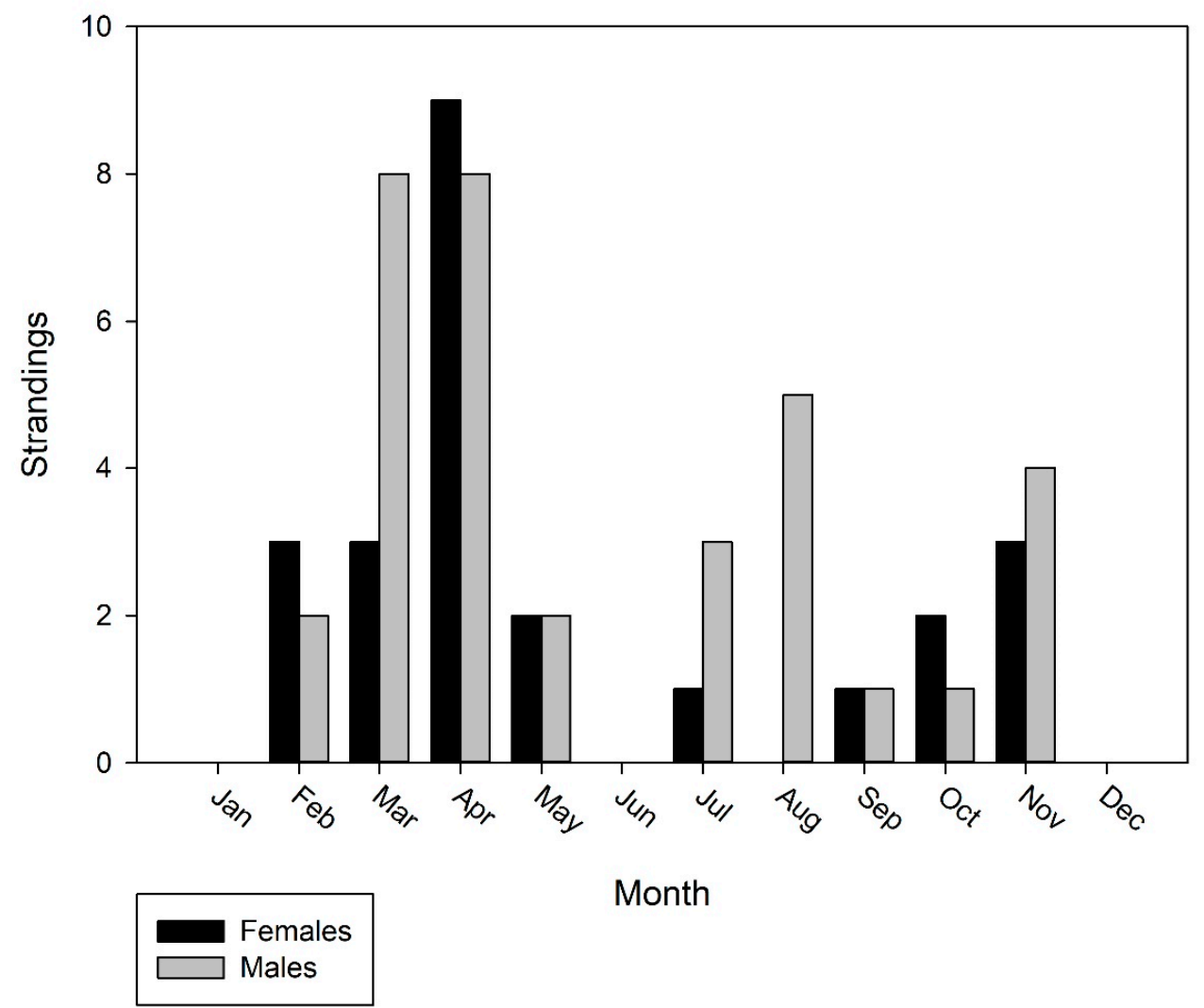

Figure 4. Kemp's ridley sea turtle, Lepidochelys kempii, strandings included in the present study by month collected. Data is summarized for all years, 1994-1999. Increasing gonadal activity associated with seasonal reproductive activity occurs between November and April. Kemp's ridleys nest in Mexico and Texas, USA, from March through August. 
A long-term study of loggerhead sea turtles, Caretta caretta, described the appearance of the gonadal tissue during puberty as observed by laparoscope [38]. Loggerheads also exhibit an overlap in carapace length between nesting adults and pubertal sub-adults, taking an estimated 4 years to complete the maturation process. As with ridleys, examination of gonad tissue to verify the sex of stranded loggerheads has been shown to be an effective technique [30]. Documentation of the external morphology of gonads alone resulted in the correct determination of sex for $92 \%$ of samples. However, Lazar [29] remarked that preservation or freezing of gonad tissue altered the appearance, making it more difficult to identify and compare with descriptions [24,38] from live animals using laparoscopy.

Additional factors such as variation in diet have been known to influence size at maturity $[23,33]$. Greater differences in resource allocation may occur in males, since they exhibited a larger range from smallest adult to largest juvenile ( $5.8 \mathrm{~cm}$ SCL, Figure 3$)$ compared to females ( $1.5 \mathrm{~cm} \mathrm{SCL}$, Figure 1$)$. This difference could also indicate variation in genetic predisposition to size, greater variation in resource acquisition, or competition for resources among males, as well as differences in reproductive demands for males and females $[23,33,35]$.

The Kemp's ridley population has increased since 1985, when only 702 nests were documented worldwide, to over 24,500 nests recorded in Mexico alone in 2017 [39]. It is important to mark their recovery as the monumental success of a bi-national effort. In spite of the fact that the Kemp's ridley population is more robust, full recovery will require diligence and continued monitoring and re-evaluation to protect population gains and prevent a backslide [13,40]. Effective management is dependent on tracking changes in population demographics, such as size at sexual maturity and age at first nesting [14,23]. The samples in this study were collected between 1994-1999, when Kemp's ridley nesting was just starting to increase [12]. Further research on the changing population status is warranted. Documentation of any future changes in size (SCL) at maturity of Kemp's ridleys would be informative to the demographics and population modeling for this imperiled species. From 2009 to 2015, the annual number of Kemp's ridley nests worldwide slowed from the former exponential increase. Gallaway et al. [13] suggested that the increased abundance of individuals in younger age classes may be exhibiting some form of density dependence or foraging level stress. Although certain ecological models investigating the complexity of density dependence generally in aquatic populations may not point to a direct cause for concern [37], foraging site fidelity exhibited by adult female Kemp's ridleys [41] could contribute to some overcrowding over multiple areas. Benthic crab species make up nearly $90 \%$ of adult and juvenile Kemp's ridleys' diet [42,43]. Populations of benthic crab species in the Gulf could be reduced due to stress from increased depredation as well as other environmental and anthropogenic factors, such as rising oceanic temperatures or the Deepwater Horizon oil spill, though these impacts have not been clearly documented. Additionally, further research on changes in size at maturity could aid in documenting the effects of density dependence on the pace of maturation.

The results of our study suggest that future necropsies of intact dead Kemp's ridley turtles larger than $50.0 \mathrm{~cm}$ SCL should include documentation of the gonads through photographs and measurements of gonad length. Additionally, we suggest that a maturity and reproductive status classification scale should be developed to classify necropsied Kemp's ridleys through comparison of measurements and photographs. The slowed recovery of the Kemp's ridley and the increase in numbers of stranded sea turtles recorded in the Gulf of Mexico from 2010-2013 [12-14] make it clear that the challenges for this critically endangered species are not over. Stranded sea turtles can provide a source of valuable information. These data are useful for documenting baselines and confirming size estimates used for determining age classes in demographic models, thus allowing wildlife managers make informed decisions regarding the conservation of this critically endangered species.

Author Contributions: K.S.C. and D.J.S. conceived and designed the experiments; K.S.C and D.J.S. provided the data; J.Y.S.H. analyzed the data; K.S.C wrote the first draft version; K.S.C., J.Y.S.H., D.J.S., J.S.W., M.R.V.-G., and D.W.O. reviewed and edited the final version.

Funding: This research received no external funding. 
Acknowledgments: We express our gratitude to National Park Service employees and volunteers for recovery and documentation of stranded sea turtles for this study. We also thank Cynthia Rubio, NPS, for necropsy, gonad collection, and preservation. We would like to thank David W. Owens and the Biology Department at Texas A\&M University for the laboratory space and resources to carry out the tissue analysis. This research was conducted under Endangered Species Permits from US Fish and Wildlife Service and Texas Parks and Wildlife Department.

Conflicts of Interest: The authors declare no conflict of interest.

\section{References}

1. IUCN. The IUCN Red List of Threatened Species. Version 2019.1. Available online: http://www.iucnredlist.org (accessed on 22 March 2019).

2. Shaver, D.J.; Schroeder, B.A.; Byles, R.A.; Burchfield, P.M.; Pena, J.; Marquez, R.; Martinez, H.J. Movements and home ranges of adult male Kemp's ridley sea turtles (Lepidochelys kempii) in the Gulf of Mexico investigated by satellite telemetry. Chelonian Conserv. Biol. 2005, 4, 817-827.

3. Shaver, D.J.; Hart, K.M.; Fujisaki, I.; Rubio, C.; Sartain-Iverson, A.R.; Pena, J.; Gomez Gamez, D.; de Jesus Gonzales Diaz Miron, R.; Burchfield, P.M.; Martinez, H.J.; et al. Migratory corridors of adult female Kemp's ridley turtles in the Gulf of Mexico. Biol. Conserv. 2016, 194, 158-167. [CrossRef]

4. Bevan, E.; Wibbles, T.; Najera, B.M.Z.; Sarti, L.; Martinez, F.I.; Cuevas, J.M.; Gallaway, B.J.; Pena, L.J.; Burchfield, P.M. Estimating the historic size and current status of the Kemp's ridley sea turtle (Lepidochelys kempii) population. Ecosphere 2016, 7, e01244. [CrossRef]

5. Heppell, S.S.; Burchfield, P.M.; Pena, L.J. Kemp's ridley recovery: How far we have come, and where are we headed? In Biology and Conservation of Ridley Sea Turtles; Plotkin, P.T., Ed.; Johns Hopkins University Press: Baltimore, MD, USA, 2007; pp. 325-335.

6. NMFS. Bi-national Recovery Plan for the Kemp's ridley Sea Turtle (Lepidochelys kempii); United States Fish and Wildlife Service: Silver Spring, MD, USA, 2011.

7. Caillouet, C.W., Jr.; Shaver, D.J.; Teas, W.G.; Nance, J.M.; Revera, D.B.; Cannon, A.C. Relationship between sea turtle strand rates and shrimp fishing intensities in the northwestern Gulf of Mexico: 1986-1989 versus 1990-1993. Oceanogr. Lit. Rev. 1996, 11, 1168-1169.

8. Shaver, D.J. Sea turtle strandings in Texas. In Report of the Sea Turtle Health Assessment Workshop, 2-3 February 1998, Part I: Background and Information Needs, Charleston, South Carolina; Fair, P.A., Hansen, L.J., Eds.; NOAA Technical Memorandum: Charleston, SC, USA, 1998; pp. 75-80.

9. Lewison, B.; Crowder, L.; Shaver, D.J. The impact of Turtle Excluder Devices and fisheries closures on loggerhead and Kemp's ridley strandings in the western Gulf of Mexico. Conserv. Biol. 2003, 17, 1089-1097. [CrossRef]

10. Frazier, J.; Arauz, R.; Chevalier JFormia, A.; Fretey, J.; Godfrey, M.H.; Marquz, M.R.; Pandav, B.; Shanker, K. Human turtle interactions at sea. In Biology and Conservation of Ridley Sea Turtles; Plotkin, P.T., Ed.; Johns Hopkins University Press: Baltimore, MD, USA, 2007; pp. 253-295.

11. Caillouet, C.W., Jr.; Putman, N.F.; Shaver, D.J.; Valverde, R.A.; Seney, E.E.; Lohmann, K.J.; Mansfield, K.L.; Gallaway, B.J.; Flanagan, J.P.; Godfrey, M.H. A call for evaluation of the contribution made by rescue, resuscitation, rehabilitation, and release translocations to Kemp's ridley sea turtle (Lepidochelys kempii) population recovery. Herpetol. Conserv. Biol. 2016, 11, 486-496.

12. Gallaway, B.J.; Gazey, W.J.; Caillouet, C.W., Jr.; Plotkin, P.T.; Grobois, A.A.; Amos, A.F.; Burchfield, P.M.; Carthy, R.R.; Castro Martínez, M.A.; Cole, J.G.; et al. Development of a Kemp's ridley sea turtle stock assessment model. Gulf Mex. Sci. 2016, 33, 138-157. [CrossRef]

13. Gallaway, B.J.; Gazey, W.J.; Wibbels, T.; Bevan, E. Evaluation of the status of the Kemp's ridley sea turtle following the 2010 Deepwater Horizon oil spill. Gulf Mex. Sci. 2016, 33, 192-202.

14. Caillouet, C.W., Jr.; Shaver, D.J.; Landry, A.M., Jr.; Owens, D.W.; Pritchard, P.C. 2011. Kemp's ridley sea turtle (Lepidochelys kempii) age at first nesting. Chelonian Conserv. Biol. 2011, 10, 288-293. [CrossRef]

15. Crowder, L.B.; Hopkins-Murphy, S.R.; Royle, J.A. Effects of turtle excluder devices (TEDs) on loggerhead sea turtle strandings with implications for conservation. Copeia 1995, 1995, 773-779. [CrossRef]

16. Magnuson, J.J.; Bjorndal, K.A.; DuPaul, W.D.; Graham, G.L.; Owens, D.W.; Peterson, C.H.; Pritchard, P.C.H.; Richardson, J.I.; Saul, G.E.; West, C.W. Decline of the Sea Turtles: Causes and Prevention; National Research Council, National Academy Science Press: Washington, DC, USA, 1990.

17. Shaver, D.J.; (Padre Island National Seashore, Corpus Christi, TX, USA). Personal communication, 2019. 
18. National Marine Fisheries Service (NMFS) and US Fish; Wildlife Service (USFWS). Kemp's Ridley Sea Turtle (Lepidochelys kempii) 5-Year Review: Summary and Evaluation; NMFS and USFWS: Silver Spring, MD, USA, 2015.

19. Crowder, L.B.; Crouse, D.T.; Heppell, S.S.; Martin, T.H. Predicting the impact of turtle excluder devices on loggerhead sea turtle populations. Ecol. Appl. 1994, 4, 437-445. [CrossRef]

20. Heppell, S.S.; Crowder, L.B.; Crouse, D.T. Models to evaluate headstarting as a management tool for long-lived turtles. Ecol. Appl. 1996, 6, 556-565. [CrossRef]

21. Scott, R.; Marsh, R.; Hays, G.C. Life in the really slow lane: Loggerhead sea turtles mature late relative to other reptiles. Funct. Ecol. 2012, 26, 227-235. [CrossRef]

22. Avens, L.; Snover, M.L. Age and age estimation in sea turtles. In The Biology of Sea Turtles; Wyneken, J., Lohmann, K.J., Musick, J.A., Eds.; CRC Press: Boca Raton, FL, USA, 2013; Volume 3, pp. 97-133.

23. Avens, L.; Goshe, L.R.; Coggins, L.; Shaver, D.J.; Higgins, B.; Landry, A.M.; Bailey, R. Variability in age and size at maturation, reproductive longevity, and long-term growth dynamics for Kemp's ridley sea turtles in the Gulf of Mexico. PLoS ONE 2017, 12, e0173999. [CrossRef] [PubMed]

24. Johnson, D.E. Applied Multivariate Methods for Data Analysis; Brooks/Cole Publishing: Pacific Grove, CA, USA, 1998.

25. Xue, J.; Titterington, D.M. Do unbalanced data have a negative effect on LDA? Pattern Recognit. 2007, 41, 1558-1571. [CrossRef]

26. Hintze, J. NCSS; NCSS, LLC.: Kaysville, UT, USA, 2007.

27. Hamann, M.; Limpus, C.J.; Owens, D.W. Reproductive cycles of males and females. In The Biology of Sea Turtles; Lutz, P.L., Musick, J.A., Wyneken, J., Eds.; CRC Press: Boca Raton, FL, USA, 2003; Volume 2, pp. 135-161.

28. Rostal, D.C. Seasonal Reproductive Biology of the Kemp's ridley sea turtle (Lepidochelys kempii): Comparison of captive and wild populatons. Chelonian Conserv. Biol. 2004, 4, 786-798.

29. Wyneken, J.; Epperly, S.P.; Crowder, L.B.; Vaughan, J.; Esper, K.B. Determining sex in posthatchling loggerhead sea turtles using multiple gonadal and accessory duct characteristics. Herpetologica 2007, 63, 19-30. [CrossRef]

30. Lazar, B.; Lackovic, G.; Casale, P.; Freggi, D.; Tvrtkovic, N. Histological validation of gonad gross morphology to sex juvenile loggerhead sea turtles (Caretta caretta). Herpetol. J. 2008, 18, 137-140.

31. Ball, G.F.; Wade, J. The Value of Comparative Approaches to our Understanding of Puberty as Illustrated by Investigations in Birds and Reptiles. Horm. Behav. 2013, 64, 211-214. [CrossRef]

32. Marquez-M, R. Synopsis of the Biological Data on the Kemp's Ridley Turtle, Lepidochelys Kempii (Garman, 1880); NOAA Technical Memo NMFS-SEFSC 343; US Dept of Commerce: Miami, FL, USA, 1994.

33. Bjorndal, K.A.; Parsons, J.; Mustin, W.; Bolton, A.B. Variation in age and size at sexual maturity in Kemp's ridley sea turtles. Endanger. Species Res. 2014, 25, 57-67. [CrossRef]

34. Caillouet, C.W. Interruption of the Kemp's ridley population's pre-2010 exponential growth in the Gulf of Mexico and its aftermath: One hypothesis. Mar. Turt. Newsl. 2014, 143, 1-7.

35. Snover, M.L.; Hohn, A.A.; Crowder, L.B.; Heppell, S.S. Age and growth in Kemp's ridley sea turtles: Evidence from mark recapture and skeletochronology. In Biology and Conservation of Ridley Sea Turtles; Plotkin, P.T., Ed.; Johns Hopkins University Press: Baltimore, MD, USA, 2007; pp. 89-105.

36. Owens, D.W. Hormones in the life history of sea turtles. In The Biology of Sea Turtles; Lutz, P.L., Musick, J.A., Eds.; CRC Press: Boca Raton, FL, USA, 1997; pp. 315-341.

37. Miller, J.D.; Limpus, C.J. Ontogeny of Marine Turtle Gonads. In The Biology of Sea Turtles; Lutz, P.L., Musick, J.A., Wyneken, J., Eds.; CRC Press: Boca Raton, FL, USA, 2003; pp. 199-224.

38. Limpus, C.J. Puberty and first breeding in Caretta caretta. In Proceedings of the Tenth Annual Workshop on Sea Turtle Biology and Conservation; Technical Memorandum NMFS-SEFC-278; Richardson, T.H., Richardson, J.I., Donnelley, M., Eds.; NOAA: Miami, FL, USA, 1990; pp. 81-83.

39. Caillouet, C.W., Jr.; Raborn, S.W.; Shaver, D.J.; Putman, N.F.; Gallaway, B.J.; Mansfield, K.L. Did Declining Carrying Capacity for the Kemp's Ridley Sea Turtle Population within the Gulf of Mexico Contribute to the Nesting Setback in 2010-2017? Chelonian Conserv. Biol. 2018, 17, 123-133. [CrossRef]

40. Kocmoud, A.R.; Hsiao-Hsuan, W.; Grant, W.E.; Gallaway, B.J. Population dynamics of the endangered Kemp's ridley sea turtle following the 2010 oil spill in the Gulf of Mexico: Simulation of potential cause-effect relationships. Ecol. Model. 2019, 392, 159-178. [CrossRef]

41. Shaver, D.J.; Hart, K.M.; Fujisaki, I.; Bucklin, D.; Iverson, A.R.; Rubio, C.; Backof, T.F. Foraging area fidelity for Kemp's ridleys in the Gulf of Mexico. Ecol. Evol. 2013, 3, 2002-2012. [CrossRef] [PubMed] 
42. Hildebrand, H.H. A historical view of sea turtle populations in the western Gulf of Mexico. In Biology and Conservation of Sea Turtles; Bjorndal, K., Ed.; Smithsonian Institution Press: Washington, DC, USA, 1981; pp. 447-454.

43. Shaver, D.J. Feeding ecology of wild and head-started Kemp's ridley sea turtles in south Texas waters. J. Herpetol. 1991, 25, 327-334. [CrossRef] 